\title{
DEFINING TERRITORIES IN AQUATIC PUBLIC SPACES: A CASE STUDY OF IJO MIGRANT FISHERMEN IN NIGERIA
}

\author{
Warebi Gabriel Brisibe ${ }^{* 1} 凹$ iD \\ ${ }^{* 1}$ Department of Architecture, Faculty of Environmental Sciences Rivers State University, Port- \\ Harcourt, Nigeria
}

DOI: https://doi.org/10.29121/granthaalayah.v9.i1.2021.3094

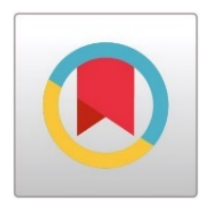

Article Type: Research Article

Article Citation: Warebi Gabriel Brisibe. (2021). DEFINING TERRITORIES IN AQUATIC PUBLIC SPACES: A CASE STUDY OF IJO MIGRANT FISHERMEN IN NIGERIA. International Journal of Research GRANTHAALAYAH, 9(1), 279-289. https://doi.org/10.29121/granthaa layah.v9.i1.2021.3094

Received Date: 28 December 2020

Accepted Date: 31 January 2021

\section{Keywords:}

Territoriality

Migration

Architecture

Aquatic Spaces

Public Spaces

\begin{abstract}
This paper examines the issue of territoriality in aquatic public spaces and how it affects fishing rights amongst artisanal fishermen of Ijo ethnic origin, in the Niger Delta area of Nigeria. It focuses on how these fishermen view the concept of space and define territories with or without the play of architectural materiality and elements. The study adopts a qualitative approach using interviews, focus groups and oral history as methodologies. The findings show that although architecturally defined boundaries in form of markings or spatial demarcations are not common in the estuarine and riverine zones of the Niger Delta, they however exist. Often implied or expressed by actions indicative of territoriality, or even revealed through other anthropological symptoms.
\end{abstract}

\section{INTRODUCTION}

The subjects of this study are migrant fishers. These are fishers who practice the fishing livelihood for subsistence or trade purposes using locally made fishing equipment and are known to operate either a cyclical migratory pattern (Ezewu and Tahir 1997) or a commuting mobility pattern (Symanski et al 1975) annually. As such, they have been categorized as nomads by the Nigerian Population Commission and Board for Nomadic Education in Nigeria. So, with migration being such a key factor in their livelihoods, how these nomads view the concept of space and define territories is worth investigating. This is because their perception of the relative degree of tenure in prospective fishing spots needs to be understood from a migratory perspective. Prussin (1995) states that

Space is often used metaphorically to evoke the idea of an unbounded or limited extension in all directions, but the concept is defined and articulated in terms of boundary and direction.... but for many nomads, architecturally defined boundaries do not exist (1995:34)

Although architecturally defined boundaries in form of markings or spatial demarcations may not necessarily exist in open aquatic ranges and fishing grounds, they can however be implied, maintained by actions indicative of territoriality or even revealed through other anthropological symptoms. This study seeks to understand how these

(C) 2021 The Author(s). This is an open access article distributed under the terms of the Creative Commons Attribution License, which permits unrestricted use, distribution, and reproduction in any medium, provided the original author and source are credited. 
migrant fishers perceive unbounded spaces, mark and maintain territories in open aquatic spaces or aquatic public spaces.

\subsection{TERRITORIALITY}

Territoriality is an area of research that has received a lot of attention in the various disciplines of the social sciences, such as sociology, human ecology, anthropology and environmental psychology amongst others. However, territoriality in architectural research is still gaining ground with scholars like Newman (1973) whose work on defensible spaces opened up issues on territoriality, Habraken $(1982,1998)$ and Karrholm $(2005,2007,2008$ and 2012). But it is Karrholm's attempt at connecting territoriality and architecture with particular emphasis on public retail spaces that provides a good premise for this study. This is because Karrholm's (2012) work examined territoriality in open public spaces where there are layers of shared access and uses and no clear-cut spatial demarcations. Similarly, this study focuses on open public spaces albeit aquatic spaces with similar issues relating to accessibility, use and non-spatial demarcations. Earlier works like those of Cashdan (1983) view territoriality as a form of resource management that works by the control and/or limitation of access to certain environmental resources within a specified area. Areas with static resources like vegetation or stagnant water bodies are easier to control or defend, whereas transient or highly mobile resources such as game, fish and birds are more difficult to defend.

\subsection{RESEARCH JUSTIFICATION}

So, to justify this attempt at examining territoriality in open aquatic spaces involving transient resources like migrating fish shoals, a number of scholarly works previously undertaken on this subject will need to be reviewed. Pinho et al (2012) explored fisheries management in relation to migration. Their work emphasizes the fact that fish populations are migratory, making the establishment of physical boundaries difficult, hence the fishers themselves are likely to move. As such, they maintain that "' spatial boundaries become ambiguous rather than fixed". Their study on local knowledge of fishers has been used in establishing cultural boundaries that aid in local fisheries management. Cinner $(2009,2011)$ also examined the issue of migration and coastal resource use in Papua New Guinea. Similar studies have also been done by Kramer et al (2002) and Berkes et al (2006) on migration and the exploitation of marine resources in open access fisheries. There have been a few studies on inshore and marine fisheries in Nigeria's Niger Delta regions (Fregene 2007; Ben-Yami 2000), Fishing rights and common pool resources (Brisibe 2016) as well as works on the architecture of Ijo migrant fishermen (Brisibe 2014, 2016b), which have served as a foundation for research work in this region. However, there is still a dearth of research in the area of territoriality as it relates to migration amongst migrant fishers in Nigeria's Niger Delta.

\section{METHODOLOGY}

The data used for this paper is obtained from one collected for a much wider study on the dwellings of these Ijo migrant fishermen. A total of 74 fishing camps were visited within the communities in Bayelsa State in Nigeria and the Bakassi Peninsula in Cameroon. In addition, a combined methods approach was adopted. For rich, in-depth information on aspects of building culture, local maritime knowledge and other forms of intangible heritage, the use of oral tradition as a data collection strategy was adopted. In addition, focus group discussions proved very useful as a means of obtaining these oral histories at the various migrant fishing base camps visited. The gathering of all the household heads in a multi-homestead base camp for discussions regarding the welfare of the camp or to settle disputes between residents is a pre-existing social practice. This practice was capitalised upon and converted into focus group sessions. The information derived from these sessions was often self-validating as any information offered by a member was likely to be confirmed, corrected or refuted by others. Factual credibility rested on collective memory which is essential for the narrative and descriptive approaches used in studies of the vernacular environment. 


\section{IJO MIGRANT FISHERS: SUBJECTS AND STUDY LOCATION}

The Ijos are one of 10 prominent migrant fishing tribes in the West African sub-region and the fourth largest ethnic group in Nigeria. They migrate to different locations along the inshore rivers of Nigeria as well as the West and Central African coastline following the movement of certain species of fish. This has contributed in spreading their population among other regions in Africa including Cameroon, Gabon, Chad and Equatorial Guinea.

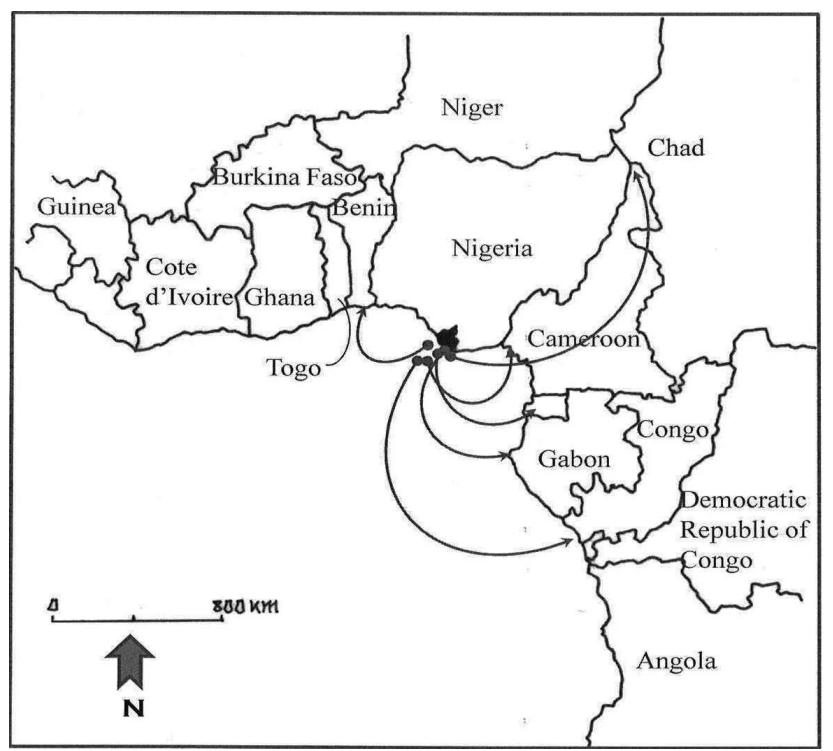

Figure 1: Outward migration to coastal regions of West and Central African Countries (Source: Author)

The few studies carried out among ljo migrant fishermen all support the fact that these fishermen relocate on a consistent basis, as dictated by fish movements. From his fieldwork at Soku in the Eastern Delta region, (Horton, 1969) commented on the undefined seasonal fish movement in those waters. He observed that,

Fish tend to congregate in different parts of the community's waters at different seasons. Then, even at a given season, they are not always to be found moving in the same way from year to year (1969:44).

This yearly change in the movement of fish could serve as a clue to offer possible explanations to the pattern of movement of these migrant fishermen. Ezewu \& Tahir (1997) argued that families migrated from one fishing village/camp to another during various fishing periods and in response to various changing tides. Sikoki and Otobotekere (1999) give a more detailed explanation of the fish movements and the migration paths that are followed as result. They believe that fishermen take advantage of seasonal distribution patterns, influenced by three main factors; moon phases; water currents; and fish behaviour. All of these are intuitively discerned and knowledge about them is traditionally transmitted through successive generations.

Moon phases are said to be instrumental in bringing in larger shoals of pelagic species due to high water levels of bi-monthly spring tides, occurring 3-4 days before the new moon and low water levels take place in similar intervals. The causative factor is attributed to the alignment of the new moon and full moon with the sun (Sikoki and Otobotekere, 1999). Of water currents, the authors state that,

During the rainy season (May - September) rough conditions in the sea restrict fishing operations by the canoe fishermen causing many of them to resort to fishing in lagoons, creeks and estuaries. During this time high fishing activity is noticeable in the brackish water zone (1999:304).

This suggests that migratory movement towards the more hinterland brackish water zone is due to the highwater currents in the marine zone, which is not suitable for fishing. Fish behaviour on the other hand varies among several existing stocks in the area and could follow the various depths at which they dwell. Also, there is the movement of fish into the floodplain following fast flow of flood water, and low oxygen tolerant fishes in swamps or inshore lakes that flow in with the flood and are trapped after the flood recedes (306-310).

Further possible causes of migration identified by (Adeyemi et al., 1997) include; marine incursion and erosion which involve unprecedented levels of sea rise that have disastrous effects for coastal villages, fishing camps and settlements. This results in fishermen moving away from the affected areas to other locations. Other reasons why 
Defining Territories in Aquatic Public Spaces: A Case Study of Ijo Migrant Fishermen in Nigeria

fishermen move include; flooding of coastal plains and river banks; the need to move away from pathways of fishing trawlers capable of destroying nets and traps and embarking on trips to market their catch in distant markets and on specific market days.

Irrespective of the diverse reasons influencing the movement of fishermen, what appears to be a constant, is the progressive eastward direction of movement observed over the years. Most scholars agree that the movement of migrant fishermen along the West African coastline have been towards the eastern part of the coast. Reverse migration westward is a rarity (Antai, 1991).

\subsection{MIGRATION AND FISHING}

The term 'migration' more often than not, conjures up an image of people travelling across international borders to take up employment either as skilled or unskilled labour. However, this term is not limited to transnational migrant workers alone but also encompasses internal migrant labour i.e., rural-rural; rural-urban; urban-rural; and urban-urban labour migration.

For internal rural-urban migration, the types of employments that hire the bulk of the labour force, which is often the pull factor for such labour migration, include large scale construction projects and industries. On the other hand, diversity of ecology, resource abundance and land tenure arrangements form the basis of the pull factor for rural-rural, as well as some urban-rural migration. Shifting cultivation for farmers and movement in search of arable land for grazing by pastoral nomads, all contribute to internal migration. Fulani herdsmen in the West African subregion are some of the best known examples of internal migrants motivated by the need to gain access to natural resource abundance (Adepoju, 1991). But there are also other less known migrants equally motivated by the abundance of natural resources and food stock; these are migrant or migrating fishermen.

Tawari (2002) defines a migrant fisherman as "one who leaves his natural community and moves from one habitation to another in fulfilment of his occupation" (2002:2). In effect, migrant fishermen are a select group of artisanal fishermen that embark on extended or prolonged foraging. Such extended foraging consequently requires a change of residence, due to the distance of the fishing grounds from their home base. Not all artisanal fishermen embark on such fishing expeditions and this suggests that, although all migrant fishermen may be 'artisanal' and not all artisanal fishermen 'migrate'. However, where Ezewu and Tahir (1997) chose to define migrant fishing based on a combination of full-time fishing practice and residential mobility, Sikoki and Otobotekere (1999) simply describes migrant fishing as a full-time vocation. They argue that the full-time status means these fishermen do not combine the fishing vocation with any other form of livelihood. In combining all these definitions, one can infer that migrant fishing is primarily extended foraging for fish, which involves residential mobility done on a full-time basis.

Having said this, the connection however between labour migration and fishermen was made by Diaw (1983) when he examined the social and production relationships amongst artisanal fishers of West Africa. In his thesis, he observed that the migration patterns practiced by these fishermen were related to two essential forms of movement in fisheries, which are, "Regulated Fishing Migrations" and "Labour Migrations". Adepoju (1991) who has carried out extensive studies on labour migration in Africa, also observed that large scale internal migration was carried out by nomads, semi-nomads and fishermen, in the West African sub-region. Similarly, Jul-Larsen and Kassibo (2001) also investigated and confirmed the existence of work migration among fishermen from Niger's Central Delta regions. These migrant fishermen also extensively practice internal and international migration as much as the conventional migrant workers. Studies conducted by (Njock and Westlund 2008; Samba and Faye, 2006; Randall, 2005) amongst others further confirm these migration patterns and previous works by the author also show that Ijo migrant fishermen practice a similar form of labour migration (Brisibe 2016b).

\subsection{AQUATIC PUBLIC SPACES AND OPEN AQUATIC RANGE}

The data on use of space reveal a number of issues. Firstly, in addition to the primary uses, certain spaces have other uses which have their importance in maintaining the overall balance of the migrant fisher lifestyle. For example, the river is not seen as just an access route but serves equally as a foraging ground and area of production, bathing facility, lavatory, and play area for children. In essence, spaces in this context are not confined to bounded interiors but are connections between the built form to natural space (De Sylva, 2008). In a similar analysis of the architecture of coastal fishers in Sri Lanka, De Sylva observes that in a fishing community, spaces accommodating 
Warebi Gabriel Brisibe

daily activities are everything between the house and the sea and this flow between spaces is of significant importance to the community. This makes open spaces ranging from immediate verandas to the entire territorial fishing grounds integral parts of the fisher's dwelling. In effect, the totality of these spaces constitutes an aquatic range. The concept of range used in this context is akin to the foraging range of hunter gatherer societies.

To understand the concept of the hunter gatherer, Ames (2004) asked the question "who is a hunter gatherer?" while Kusimba (2005) carried an inquisitive caption of "what is a hunter-gatherer?". Ames speaks of the traits and socio-cultural lifestyle based possibly on preconceptions or historically derived facts of hunter-gatherer organisational models. While Kusimba focuses on activities and practices that characterize the hunter-gatherer ideal or variations. Current discussions on hunter-gatherer classifications seem to have expanded to include variations based on type of resource exploited, foraging patterns, whether or not they produce food, and whether or not they are egalitarian. Several scholars have offered varying definitions of the hunter-gatherer over the years, but it is Ames' compilation of hunter-gatherer indicators drawn from Susan Kent's work that I consider to be most comprehensive (Ames, 2004). It states that,

Hunter-gatherers as a class are defined first, but not completely, by foraging, second by certain organizational properties (living in bands, relative egalitarianism, mobility, mobility patterns of dispersion and aggregation, and a common property regime), and third by a common cultural ethos marked by sharing and belief in a giving environment and an animated cosmos (2004:367)

Hunter-gatherers are food-producing itinerant communities. These communities are referred to universally as nomads, the most common of which is the pastoral nomad. Other societies listed as food-producers include; migrant fishermen, hunters and gatherers and shifting cultivators. Khazanov (1994), like some other scholars regarded migrant fishermen and shifting cultivators as a part of the hunter-gatherer society.

However, the question of how these hunter-gatherer societies define, mark and maintain territory, especially territory within their foraging range is worth investigating. For this, Cashdan's (1983) argument of a territorial defence type, where territory size becomes indeterminate, can be considered. This is primarily because this model has been applied in studying territoriality among human forager groups, of which migrant fishing communities are a part. It is this model that identifies 'perimeter defence' and 'social boundary defence' as territorial mechanisms inherent in human foragers. In perimeter defence, "foragers typically mark the perimeter of their territory boundary and control access to the territory space itself" (1983:49). This takes effect in the case of overt competition. Social boundary defence on the other hand, works by controlling access to the social group in the area, especially when resources become unpredictable and the foraging scope or range becomes too large to make the practice of perimeter defence feasible. While the former works by actual physical defence or manning of the territorial range, the latter works on the principle of reciprocal altruism, which is the granting of access in the hope that access, will be reciprocated when the need arises.

\section{DETERMINING AN AQUATIC RANGE IN AQUATIC PUBLIC SPACES}

Based on data obtained from oral traditions and narratives from the fishermen, a territorial fishing range for a single or multi-homestead camp can be measured as a 'shouting distance' between one camp and other. A 'shouting' distance is the radius or distance within which a shout can still be heard from a source, especially when raised for help. In the creeks of the Niger Delta, fishers' dwellings within this audible radius can be considered as being part of the territorial range of the fishing camp. But where dwellings are located beyond this radius of audibility, those other dwellings or group of dwellings assume autonomous camp status and operate within a different territorial range even if they are still visible from the neighbouring camp. It is necessary to re-iterate that each fishing camp has an aquatic territorial range within the inshore waters, where they carry out their livelihood. These territorial allotments are only obtainable within riverine and estuarine zones and do not apply to coastal or marine areas.

In the Ijo vernacular landscape, an aquatic range within the aquatic public space is known as the fishing ground. (Scott, 1989) defined fishing grounds as consisting of "the banks and floor of the stream, and the still or flowing water they contain" (pg 16). It is important to note that the fishing grounds referred to by (Ben-Yami 2000), (Hassan et al., 1997) and (Ezewu et al., 1997) may often comprise of different (secondary) sites within a particular location. Access to these secondary sites involve further yet shorter forms of relocation, brought about by adjustments to changing circumstances or further fish movement. As such, (B) or (C) on the model in fig 3 could have multiples B1, B2, B3 or C1, C2, C3 etc (Hassan et al., 1997). In essence, the fishing ground consists of several fishing spots within 
an aquatic range. This is based on the presupposition that every migrant fishing household operates within a given aquatic range or 'home range' Borrero and Barberena (2006). A typical home range could translate directly into the area a household occupies in their movement annually. It could also relate to the number of residential moves made per year or the distances travelled during an annual foraging cycle (Borrero and Barberena, 2006; Binford, 2001; Kelly, 1995). But this aquatic home range consists of different stops that are perceived as fertile fishing sites, where fish traps are set and nets are cast for a while, until the stock depletes.

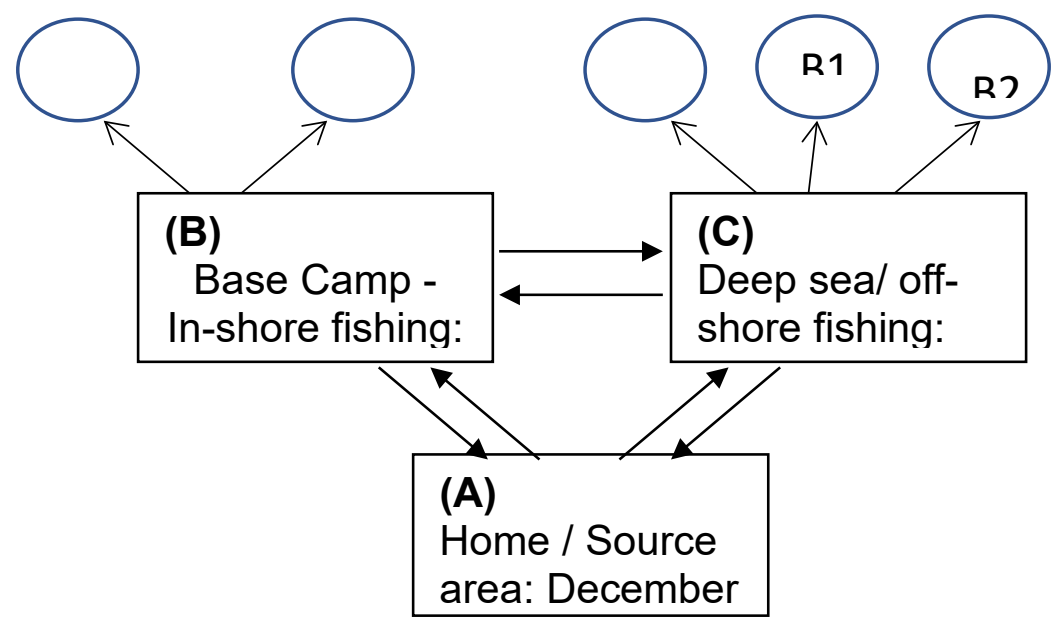

Figure 9: Annual fishing cycle of Ijo migrant fishermen showing secondary sites (Source: Adapted from Hassan et al in Ezewu \& Tahir (eds) 1997)

This idea of a home range is also reflected in the Ijo word for fishing camp. The term used for a fishing camp is often a combination of two words and sometimes with a connecting word or syllable in between. The commonly used terms are; Indidougbene/Endidougbene, Bou-rikiri, Alamendi. The first three are associated with the fresh water zone, while the last with the brackish and marine zones.

Indi or Endi = fish (slight dialectical differences)

Bou $=$ Bush or forest (usually refers to highly transient camps)

Dou $=$ find

Kiri or gbene = grounds, area - this gives no specific location or boundary definition of the area. It thus, embodies the concept of an unbounded space or an open aquatic range.

Endidougbene can then be translated as fish-finding-area. While the term bou-rikiri can be translated to mean, forest-grounds or area, the other word alamendi also possesses the constant endi but has an interesting prefix ala $=$ far (with regards to distance). In translation, it will read thus, far-fish or far fishing. This is not surprising as camps within this region are located in the coastal regions or farther off the continental shelf.

Nonetheless, fishing in an open aquatic range does not necessarily suggest that the fisheries resources in the open rivers and creeks are freely accessible to all and that fishing camps can be built anywhere arbitrarily. In the study location, fishing rights have to be obtained before fishing camp dwellings can be built.

\section{ARCHITECTURE AND TERRITORIAL FISHING RIGHTS AMONGST IJO MIGRANT FISHERS}

The concept of ownership under Ijo customary law upholds the fact that, all land (water bodies inclusive) is owned by the immediate community, and segments are entrusted to extended families and clans to administer. These larger family groups can in turn allow right of occupancy or use by any member of the family, for the practice of their chosen livelihoods indefinitely. The areas thus divided to individual members become their aquatic range for which they exercise territorial rights of access to fishing grounds, withdrawal of resources and defence. But the limitations and boundaries of this aquatic range are often not demarcated nor are they amenable to demarcation. Nonetheless, such aquatic territories can be marked by architectural features and a given radius around such features is regarded as the aquatic range for the fisherman.

Brisibe, D (1990) observed that in the case of Western Ijos, families may own whole fishing ponds or lakes but a virgin expanse of swamp land commonly called 'akpara' belongs to the community and anybody is free to clear a 
portion and settle there for the business of fishing. However, this right of ownership is limited to only the area where the fisherman puts up some dwelling like a hut or building. A reasonable area around the dwelling which can be described as a foraging range is allocated to the fisherman to operate as long as he wants but once he has abandoned the place any other person can take over the range and carry-on fishing but may not use the dwelling except by permission.

Okara (2003) also observed that migrant fishermen of Ijo ethnic origin in other communities pay for fishing licenses per boat to the host community, which in turn grants them permission to build their huts in the area. No moneys are charged for building of dwellings in any area and no tax is paid to government authorities. Here again the building of the hut is indicative of fishing rights being granted and also marks the territorial range within which the fisherman can operate.

An example of oral traditions depicting the evolution of Agoloma town, an Ijo settlement in the Niger Delta states that when the progenitor Agolomaowei settled there, he cleared a portion for farming, built a hut and occupied a strip of the territorial waters for fishing (Brisibe, E. 1986). The strip of waters around his constructed dwelling was considered his territorial range. With subsequent settlers joining him, more huts were built and with each added hut came added strips of waters for the fishermen.
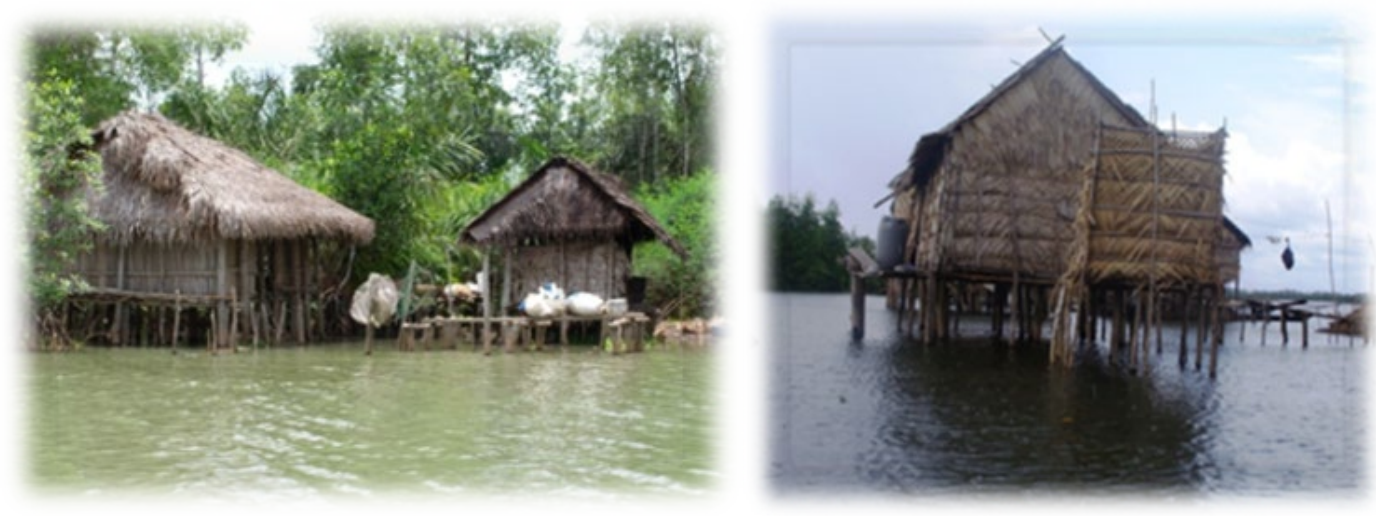

Figure 2 and 3: Sample of huts used as territorial markings in Bayelsa, Nigeria and Bakassi, Cameroon

Ezewu et al (1997) attempted to map the cyclical pattern of fishermen in response to the various mechanisms that influence migration. This was done with data obtained from time-geographical survey analysis from which the model below was produced. This has hitherto been cited as the typical migrant cycle for Ijo fishermen in the riverine and coastal communities of the Niger Delta area in Nigeria.

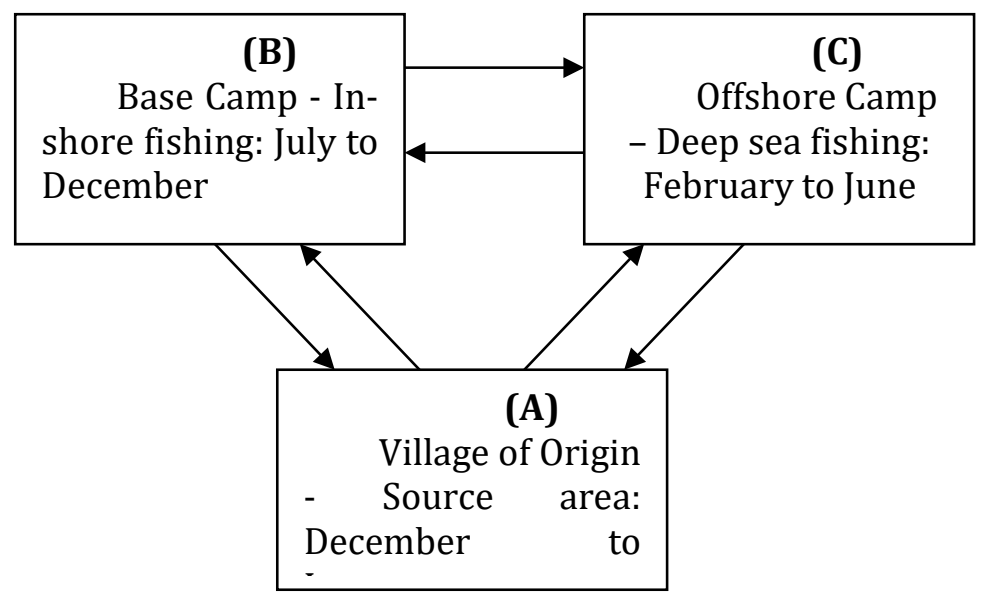

Figure 4: The annual fishing cycle of Ijo migrant fishermen (Adapted from: Ezewu \& Tahir 1997)

Hassan et al (1997) explain the migration concept using the link between the boxes. (A) is regarded as the sending society or the village of origin of the fishermen. (B) or (C) depending on the migration pattern of the fishermen could be the base camp or the off-shore camp. (Ben-Yami, 2000) offered a more lucid description of the 
three categories of fishing communities, referring to them as; permanent villages (Ama), semi-permanent base camps (Endidougbene) and fishing camp annexes (Endidoubou). Of the three locations, the base camp and annex camps are located along aquatic public spaces where the building of huts are used to establish territories. They are often established to bring the fishermen closer to the fishing grounds or aquatic range.

\subsection{OTHER TERRITORIAL MARKERS}

Aside from dwellings, other features have also been used in marking fishing territories especially around inshore ponds and lakes in brackish water swamps. The use of 'anthropological tracking' in the identification of fishing spots owned by other fishers. A term used by Thwaites and Simkins (2007) in amongst other things, identifying how space is used based on traces or tracks that reflect the type of human activity practiced in that space. Some of the effects that mark spots are highly visible architectural features like camp huts and fences, while others like nets, basket traps and simple poles tied with strings bearing fish hooks underwater, are less conspicuous markers. The ponds and lakes in the swamps are often formed when flood waters have receded. Adult fish, which have found their way into such pools because of the flood, eventually get stranded when the flood waters recede. The ponds are small, approximately waist-deep and measure less than 25sq yards but they are often well stocked with adult fish. Because reasonable income can be derived from such finds, they can easily become the cause for contention. As such, certain features are put in place as perimeter defence to indicate ownership. The features which in this case are fish fences and net pole barricades, act as markers that suggest territorial ownership to other fishermen.

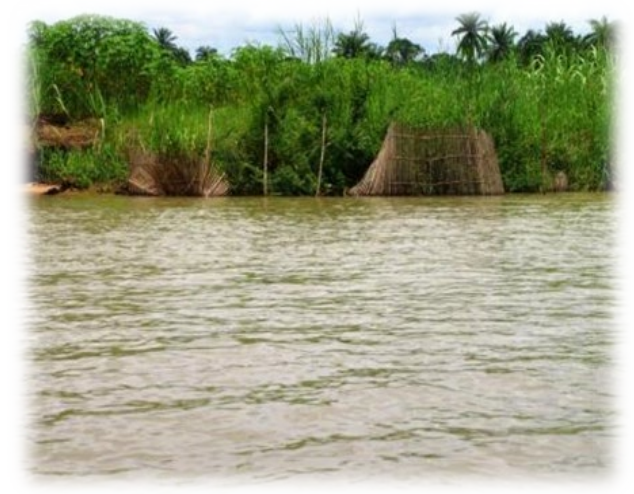

Figure 5: Fish fence or Kiddle (Lala) in use area

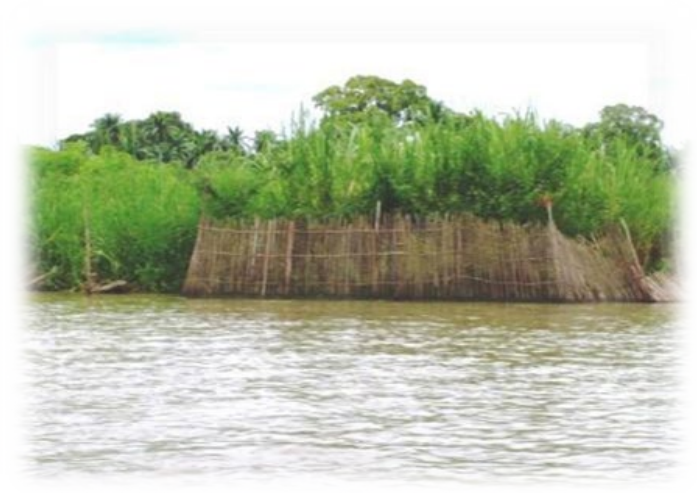

Figure 6: Fish fence used in another area

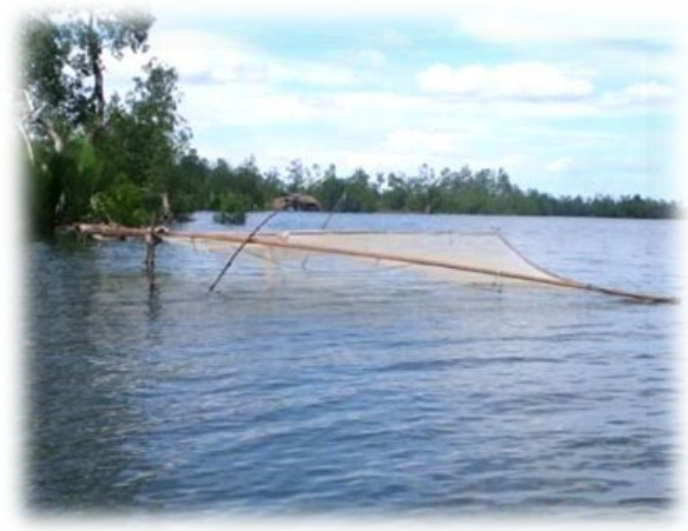

Figure 7: Net poles used in marking larger fishing grounds Figure 8: Special net for catching 'ekpai' fish

Besides inshore ponds and lakes, fishers also stake claims to spawning grounds along the river edges. These are ideal locations for baiting hooks, basket traps and setting the fish fence or kiddle. These traps have to be checked daily for harvest and re-baiting, as the trapped or hooked fish has a short trapped-life before it gets spoilt. Once any of these traps have been spotted by other fishers, they cannot set their traps within close proximity of the already 
existing traps as this constitutes an infringement on the latter's immediate fishing territory. As such, these fishers may effectively monopolize a spot for as long as collection and re-baiting activity continues. This is similar to situations that are obtainable in Iceland, Brazil and Maine. Durrenberger and Palsson (1987) referred to these similar situations as "unfortunate technical limitations that two fishing implements cannot effectively take fish from the same spot at the same time" (pg 516).

\section{DISCUSSIONS}

Previous studies have established the fact that livelihood resources like fish tend to migrate and as such groups that depend on them to survive have to migrate too. Studies have also classed migrant fishermen as hunter-gatherers and migrant labourers. But for every resource obtained from a common pool, control or management is vital to help maintain balance, equity and fairness among users. With the need for control come all forms of territorial behaviour common in all public spaces where portions are unmarked and uses layer over each other through time-share or other space allotment methods. This is manageable for landed spaces but becomes tricky for fluidy spaces like water and air. For such fluidy spaces the concept of open range or fishing grounds was also discussed in this study, giving an added perspective to territoriality in aquatic public spaces.

As stated in Brisibe (2015), when several users withdraw from a common pool resource with no physical barriers demarcating the vast aquatic range, disputes over rights of usage and contested fishing landscapes are likely to occur. From the study, architectural elements in the form of huts and local fishing equipment have been shown to be the main way aquatic territories in the study area are being marked. However, to avoid user conflict and enhance resource management and control, indicating proper boundaries along a strip of water or sub-dividing territories from the larger aquatic space requires much more than installation of architectural elements. It requires a knowledge of what constitutes fishing grounds and open ranges in the Ijo migrant fishing landscape in order to understand fishing rights. Because in aquatic public spaces seemingly belonging to no one in particular and yet belonging to all, not all resources within are actually for public use. This translates into dependence on local knowledge as a means to understanding territoriality just as it is already being used extensively in the area of fisheries management and the management of other common pool resources.

\section{SOURCES OF FUNDING}

This research received no specific grant from any funding agency in the public, commercial, or not-for-profit sectors.

\section{CONFLICT OF INTEREST}

The author have declared that no competing interests exist.

\section{ACKNOWLEDGMENT}

None.

\section{REFERENCES}

[1] Adeyemi, E. A, Fashuyi, S. A, Fatunla, G. T. and Otaigbe, P. E. “Ondo State Study”, In: Ezewu, E. E. and Tahir, G. (eds) Ecology and Education in Nigeria: Studies on the Education of Migrant Fishers, 1997, Tabansi Publishers Ltd: Onitsha, Nigeria

[2] Ames, K. M. “Supposing Hunter-Gatherer Variability" American Antiquity, 69(2), 2004, 364-374.

[3] Amire, A. V. "Monitoring, Measurement and Assessment of Fishing Capacity: The Nigerian Experience", FAO Fisheries Technical Paper, T445, 2003, 329-344.

[4] Antai, E.E. “Geographical and Ecological Features of the Project Area” In: Miller, W (ed) Procedings of Fisheries Development Extensionist Training Course, 1991, Federal Department of Fisheries: Abuja 
Defining Territories in Aquatic Public Spaces: A Case Study of Ijo Migrant Fishermen in Nigeria

[5] Ben-Yami, M "Integration of traditional institutions and people's participation in an Artisanal fisheries development project in southeastern Nigeria", In: McGoodwin, J. R (ed) Understanding the Cultures of Fishing Communities 401, 2000, FAO Fish.Tech.Paper, 133-167.

[6] Berkes, F, Hughes, T.P, Steneck, R.S, Wilson, J.A, Bellwood, D.R, Crona, B “Globalization, Roving Bandits and Marine Resources", Science 311, 2006, 1557-8

[7] Binford, L. R. "Constructing frames of reference: An analytical method for archaeological theory building using ethnographic and environmental data sets", Berkeley, 2001, University of California Press.

[8] Borrero, L. A. and Barberena, R. "Hunter-Gatherer Home Ranges and Marine Resources: An Archaeological Case from Southern Patagonia", Current Anthropology 47(5), 2006, 855-868

[9] Brisibe, E. S. "The Nature and Extent of Communal Ownership of Land in Traditional Izon Society", Unpublished LL. B Thesis, 1986, Rivers State University of Science and Technology, Port-Harcourt

[10] Brisibe, D.G "Succession to Property in Western Ijo", Unpublished LL. B Thesis, 1990, Rivers State University of Science and Technology, Port-Harcourt

[11] Brisibe, W. G. "Ijo fishing settlements in Nigeria: Facilities, spaces and activities", Journal of the International Society for the Study of Vernacular Settlements, 3(2), 2014, 35-49.

[12] Brisibe, W.G. "Common Pool Resources and Fishing Rights amongst Ijo Migrant Fishing Communities in the Niger Delta, Nigeria", Savant Journal of Research in Environmental Studies, 2(1), 2016, 001-007

[13] Brisibe, W.G. "Base Camp Architecture: examining variations in fisher dwellings in Nigeria and Cameroon", Sage Open, (January - March Issue), 2016, 1-15, DOI: 10.1177/2158244016636942

[14] Cashdan, E "Territoriality among Human Foragers: Ecological Models and an Application to Four Bushman Groups [and Comments and Reply]", Current Anthropology, 24 (1), 1983, 47-66

[15] Cinner, J. "Migration and Coastal Resource Use in Papua New Guinea”, Ocean and Coastal Management, 52(8), 2011, 411-416

[16] De Sylva, S. "Contested Thresholds and Displaced Traditions of Fisher Dwellings: A Study of Traditional Sri Lankan Coastal Architecture", Traditional Dwellings and Settlements Review, 2008, 20(1), 82

[17] Diaw, M. C. "Social and production relationships in the artisanal maritime fisheries of West Africa: A comparative analysis", 1983, Thesis, Michigan State University

[18] Durrenberger, P.E and Palsson G. "Ownership at Sea: Fishing Territories and Access to Sea Resources", American Ethnologist, 14(3), 1087, 508-522

[19] Ezewu, E. E. and Tahir, G "Ecology and Education in Nigeria: Studies on the Education of Migrant Fishers", 1997, Tabansi Publishers: Nigeria

[20] Fregene, B. T. "Profile of Fishers Migration in Nigeria and Implications for a Sustainable Livelihood", African Migrations Workshop, University of Ghana, Ghana, September 2007. 1-10

[21] Horton, R. "From fishing village to city-state: A social history of New Calabar", In: Douglas, M. (ed) Man in Africa. 1969, London. 37-58

[22] Jul-Larsen, E. and Kassibo, B. "Fishing at home and abroad - Access to waters in Niger's central Delta and the effects of work migration", in Benjaminsen, T. and Lund, C.(eds) Politics, Property and Production in the West African Sahel. 2001, Nordiska Afrikainstitutet.

[23] kàrrholm, M. "Retailising Space: Architecture, Retail and the Territorialisation of Public Space”, 2012, Ashgate Publishing Limited, England

[24] kàrrholm, M. "The Territorialization of a Pedestrian Precinct in Malmö", Urban Studies, 45 (9), 2008, 19031924

[25] [kàrrholm, M. "The Materiality of Territorial Production", Space and Culture, 10 (4), 2007, 437-453

[26] kàrrholm, M. "Territorial Complexity, a Study of Territoriality, Materiality and use at Three Squares in Lund", Nordic Journal of Architectural Research, 1/2005, 99-114

[27] Kelly, R. "The foraging spectrum: Diversity in Hunter-Gatherer Lifeways", 1995, Washington DC, Smithsonian Institution Press.

[28] Khazanov, A. M. "Nomads and the Outside World", 1994, University of Wisconsin Press

[29] Kusimba, S. B. "What Is a Hunter-Gatherer? Variation in the Archaeological Record of Eastern and Southern Africa", Journal of Archaeological Research, 13(4), 2005, 337-365.

[30] Kramer, R. A, Siman Juntak, S.M.H and Liese, C "Migration and Fishing in Indonesian Coastal Villages", Ambio 31(4), 2002, 367-372 
[31] Habraken, N.J. "The Structure of the Ordinary, Form and Control in the Built Environment". 1998, Cambridge MA: The MIT Press

[32] Habraken, N.J. “Transformation of the Site”, 1982, Chicago: ITT Press

[33] Newman, 0. "Defensible Space”, 1973, New York: Collier Books

[34] Njock, J.C. and Westlund, L. "Understanding the Mobility of Fishing People and the Challenge of Migration to Devolved Fisheries Management". In: Westlund, L., Holvoet, K. and Kebe, M. (eds) Achieving Poverty Reduction through Responsible Fisheries: Lessons from West and Central Africa. 2008, Food and Agriculture Organisation.

[35] Okara, E. U. "The Migrant Fisherman: A social and economic analysis". National institute for policy and strategic studies, Kuru: 2003, Nigeria.

[36] Olawepo, R.A. "Using Participatory Rural Appraisal to Explore Coastal Fishing in Badagry Villages". Nigeria Environmentalist 28(2), 2008, 108-122

[37] Pinho, P, Orlove, B, Labell, M. "Overcoming Barriers to Collective Action in Community-Based Fisheries Management in the Amazon". Human Organization 71(1) 2012, 99-109

[38] Prussin, L. "African Nomadic Architecture: Space, Place, and Gender". Washington and London, 1995 Smithsonian Institution Press and The National Museum of African Art.

[39] Randall, S. "Review of Literature on Fishing Migrations in West Africa - From a Demographic Perspective". Sustainable Fisheries Livelihoods Programme, FAO and DFID, 2005 pp. 40

[40] Samba, A. and Faye, M. M. "Etude de la contribution des migrations de pecheurs artisans Senegalais dans la gestion des peches en Mauritanie et en Guinee". Sustainable Fisheries Livelihoods Programme, (SFLP) 2006 (Unpublished working document) pp. 62

[41] Scott, A. D “Conceptual Origins of Rights Based Fishing”. In: Neher, P. A (ed) Rights Based Fishing, 1989, Kluwer Academic Publishers, 11-38.

[42] Sikoki, F. D. and Otobotekere, A. J. T. "Fisheries”, in Alagoa, E. J.(ed), Lands and People of Bayelsa: Central Niger Delta. 1999 Onyoma Publications Ltd, Nigeria.

[43] Symanski, R., Manners, I. R. and Bromley, R. J. "The Mobile-Sedentary Continuum", Annals of the Association of American Geographers, 65(3), 1975, 461-471.

[44] Tawari, F. Dissemination of Research Findings on Nomadic Education in Nigeria (The Migrant Fishers Education Experience): Issues and Directions. IEC/DFID Virtual and Physical Conference: Education for Nomads, Pastoralists and Migrant Fisherfolk. Abuja, Nigeria, 16-19th January 2002. 